\title{
A Reflection and Analysis of the Waste Rock Dump Closure Strategies at Kidston Gold Mine
}

\author{
D.J. Williams The University of Queensland, Australia
}

D.R. Mulligan The University of Queensland, Australia

N.A. Currey Klohn-Crippen Berger, Australia

\section{INTRODUCTION}

The rehabilitation of potentially acid forming waste rock is site specific, being a function, among other factors, of the rock types, the dumping and storage method employed, and the climatic setting. At Kidston Gold Mine in north Queensland, Australia, a vegetated "store/release" cover was developed (Williams et al., 1997) for the flat top surfaces of the encapsulated mineralised waste rock dumps to manage acid rock drainage in this semi-arid, seasonal, sub-tropical climate. The covers were instrumented with moisture and suction sensors and lysimeters and have been monitored for up to nine years. In the first part of the paper, the philosophy behind the "store/release" cover design and its adaptation over time to suit Kidston's conditions are described. The results of monitoring of the cover are presented, along with the data collected on seepage rates and water quality, and projected seepage rates.

In the second part of the paper, the revegetation aspects of the rehabilitation of Kidston's waste rock dumps are described. An effective vegetation cover is integral to the successful performance of the store/release cover on the flat top surfaces of the waste rock dumps. In 1996, a species trial was established on the earliest store/release cover trial on the South Waste Rock Dump. This study screened a wide range of local eucalypt and acacia species for their suitability to the oxide waste that constituted the root zone material. A second trial objective was to test several native grasses for their tolerance of the conditions, both alone and in combination with the tree/shrub component. From the findings of these initial trials, the larger scale revegetation strategy for the waste rock dumps at Kidston was developed. In the 2001/2002 wet season, the surfaces of the store/release covers were direct seeded with tree and shrub species, and this was followed by the seeding of pasture species 12 months later. Since that time, the progression of the vegetation communities developing on the waste rock dumps has been monitored and the outcomes from these assessments are presented. The philosophy behind, and research to support, the strategy for the angle-ofrepose outer batters of the waste rock dumps are also described.

Mining operations at Kidston ceased in 2001, and the ongoing monitoring data that The University of Queensland is accumulating and interpreting over time is all a part of a major program that is directed towards generating confidence in the long-term performance of the waste rock dump covers. The projections from these studies enable an understanding of residual risks and provide informed support to the decisionmaking processes that are required for timely relinquishment of the lease.

\section{$1.1 \quad$ Site Setting}

Kidston Gold Mines are located in North Queensland, Australia, approximately $280 \mathrm{~km}$ south west of Cairns (Williams et al., 1997; Kidston Gold Mines Limited, 2000). The elevation of the site is about $540 \mathrm{~m}$ Australian Height Datum (AHD). The climatic setting of Kidston Gold Mines is semi-arid, sub-tropical, with pronounced wet and dry seasons. On average, $82 \%$ of the annual rainfall falls between November and April, with high intensity storms being common. The annual rainfall averages about $700 \mathrm{~mm}$, but it can range from a low of $400 \mathrm{~mm} /$ year to a high of $1500 \mathrm{~mm} /$ year. The average pan evaporation is about $2800 \mathrm{~mm}$, four times the average annual rainfall. Average daily winter temperatures range between a minimum of $-2 \mathrm{C}$ and a maximum of $22 \mathrm{C}$. Average daily summer temperatures range between a minimum of $23 \mathrm{C}$ and a maximum of $36 \mathrm{C}$. The prevailing wind direction is from the east to south east. 
The topography of the site is generally gently sloping, with rocky "knolls" rising about $50 \mathrm{~m}$ above the surrounding topography. The site vegetation is an altered open woodland, comprising native grasses, ironbark trees and Gilbert river boxes, supporting semi-domestic cattle, wild pigs, native animals and a prolific bird life.

\subsection{Overview of Surface Waste Rock Disposal}

The waste rock included oxide (weathered) waste rock, fresh (inert) barren waste rock, and mineralised waste rock. The waste rock from Wises Hill Pit was truck dumped in surface engineered dumps surrounding the pit. The $20 \mathrm{Mt}$ (about one sixth of the total waste rock placed in surface dumps) of mineralised waste rock excavated from Wises Hill Pit was placed in the South and North Waste Rock Dumps on a pad of fresh barren waste rock, with a wide encapsulation (up to $60 \mathrm{~m}$ horizontally) of fresh barren waste rock. The waste rock dumps were typically constructed to a height of about $36 \mathrm{~m}$ by end-dumping over the crest of the dump. The waste rock types were selectively placed, based on their identified geology and inferred acid rock drainage potential. The final surface waste rock dump footprint covered about 340 ha and the dumps contain about 120 Mt of waste rock.

\subsection{Geochemical Characterisation of Mineralised Waste Rock}

The sub-economic mineralised waste rock is potentially acid forming. It has a gold content in the range from 0.55 to $0.7 \mathrm{~g} / \mathrm{t}$, a typical total sulphur content of $0.9 \%$, an Acid Neutralisation Capacity (ANC) of $54 \mathrm{~kg}$ of $\mathrm{CaCO}_{3}$ per $\mathrm{t}$ of material, a Net Acid Producing Potential of $-24 \mathrm{~kg}$ of $\mathrm{CaCO}_{3}$ per $\mathrm{t}$ of material, and an ANC/MPA (MPA = Maximum Potential Acidity) of 1.8. The potential for the mineralised waste rock to produce acidity was realised when the $\mathrm{pH}$ of the seepage emanating from the South (mineralised waste rock) Dump dropped suddenly during the extreme 1990/91 wet season from about 7.5 to about 4.5, about 4 years after the start of construction of the dump.

\section{STORE/RELEASE TOP SURFACE COVER}

\subsection{Philosophy Behind Store/Release Cover System}

The mineralised waste rock that comprised about one sixth of the total waste rock stored in surface dumps at Kidston was placed on a pad of fresh barren waste rock and encapsulated laterally by fresh barren waste rock. It was required to construct a low permeability cover over the mineralised waste rock to limit rainfall infiltration and hence limit any acid drainage, with any reduction in oxygen ingress being a bonus. It was recognised that in Kidston's highly seasonal and variable semi-arid climate, a rainfall-shedding cover would not be a sustainable means of minimising rainfall infiltration into the mineralised waste rock. During the long dry season, the oxide waste rock available for cover construction would desiccate leading to vegetation die-back. The subsequent summer storms would then erode the desiccated, poorly vegetated surface, with the likelihood of breaking through the cover.

Instead, a store/release cover system was developed for Kidston (Williams et al., 1997), which recognised the need to avoid desiccation and the eroding effects of rainfall runoff, and relied on storage within the cover of rainfall infiltration during the short wet season and its release during the long subsequent dry season through evapotranspiration.

The store/release cover system had the following aims.

- To provide a cover with sufficient water storage capacity to "store" the bulk of the 3-month summer wet season rainfall, without causing saturated breakthrough into the underlying mineralised waste rock, limiting rainfall infiltration through the cover to $<5 \%$ of annual rainfall.

- To "release" the stored water through evapotranspiration during the 9-month dry season, while maintaining the compacted clayey layer at the base of the cover moist to preserve its integrity. The vegetative cover plays a key role in ensuring that this aim is met.

- To provide a cover system that cycles annually between wet and dry states, without progressively wetting up or drying out. 
An encapsulation of inert waste rock under the base and around the sides of the mineralised waste rock was provided, over which the store/release cover extended. The side encapsulation was wide enough to ensure that any rainfall infiltrating the sides of the dump will not intercept mineralised waste rock and generate acid drainage. The outer batter slopes were left at the angle of repose of the inert waste rock (nominally $38^{\circ}$ ) and over-dumped with oxide waste rock from the crest to facilitate revegetation.

\subsection{South Dump Store/Release Cover Trial}

A schematic of the original store/release cover system used for the 23 ha South Waste Rock Dump trial cover is shown on Figure 1. Prior to the construction of the store/release cover, the top of the rock dump was sloped to prevent the ponding of any water that penetrates the cover. A near-saturated $0.5 \mathrm{~m}$ thick compacted clayey (fine-grained oxide waste rock) sealing layer was then placed, overlain by a loose rocky soil mulch (coarse-grained oxide waste rock) layer a minimum $1.5 \mathrm{~m}$ thick, which serves as the store/release layer and protects the underlying compacted clayey sealing layer.

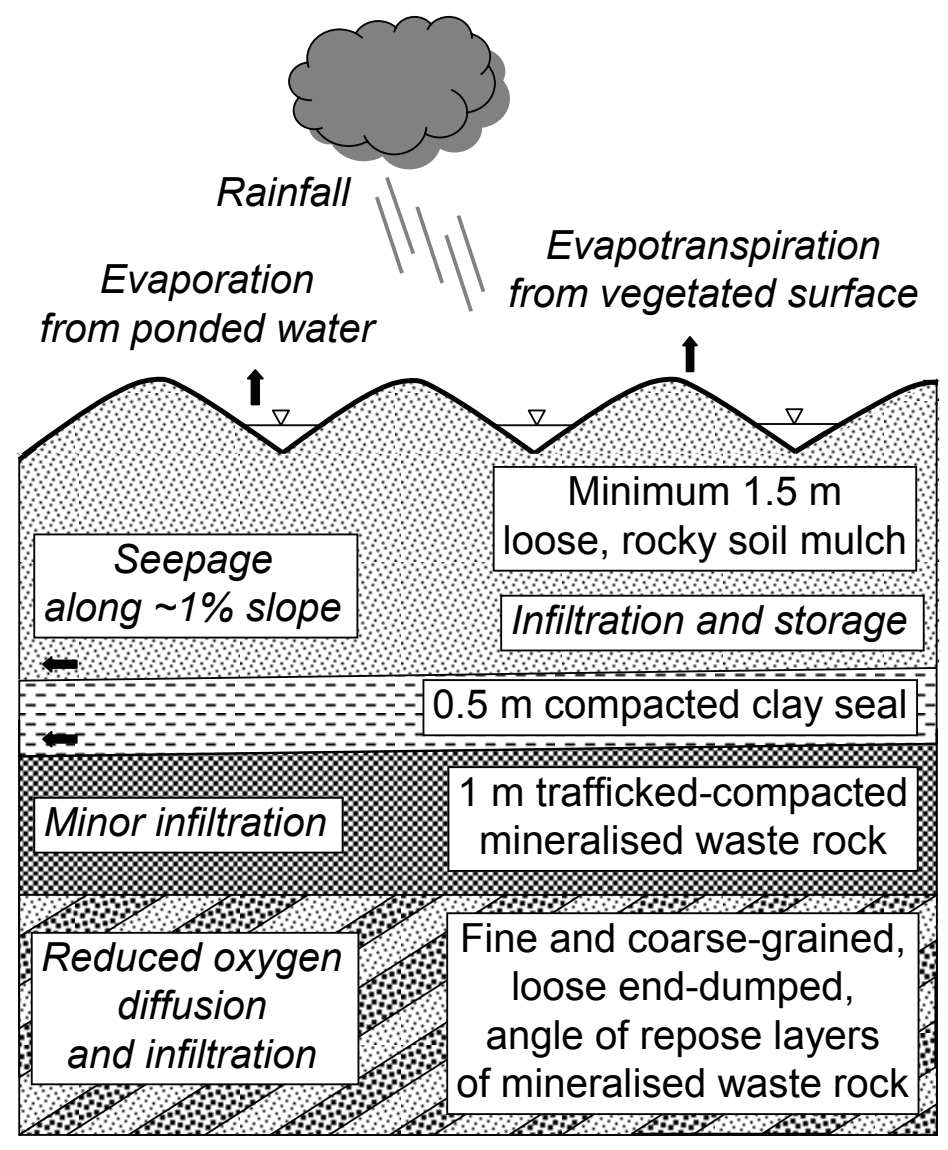

\section{Figure 1 Schematic of original store/release cover system used for South Dump trial}

The rocky soil mulch layer was placed by paddock dumping from haul trucks, forming a hummocked surface profile that prevented rainfall runoff, which would erode the cover. The surface was vegetated to ensure sufficient transpiration to just remove the stored water without excessively drying out the cover. The store/release cover extended over both the mineralised waste rock and the fresh barren waste rock side encapsulation, to avoid rainfall infiltration through the side slopes of the dump intercepting mineralised waste rock. The dump side slopes were left at the angle of repose of the fresh barren waste rock, ensuring both adequate geotechnical and erosional stability. Oxide waste rock was over-dumped from the crest and the slope aerially grass seeded and fertilised.

Laboratory falling head testing of compacted clayey oxide waste rock gave saturated hydraulic conductivity values of between $5 \times 10^{-10} \mathrm{~m} / \mathrm{s}$ and $2 \times 10^{-8} \mathrm{~m} / \mathrm{s}$ (between $15 \mathrm{~mm} /$ year and $630 \mathrm{~mm} /$ year). Field permeability 
testing of the compacted clayey oxide waste rock indicated a typical saturated hydraulic conductivity of about $10^{-8} \mathrm{~m} / \mathrm{s}(315 \mathrm{~mm} /$ year $)$. The particle size distribution of the clayey oxide waste rock used to form the sealing layer comprised typically $10 \%$ clay (passing $0.002 \mathrm{~mm}), 15 \%$ silt $(0.002$ to $0.06 \mathrm{~mm}), 35 \%$ sand (0.06 to $2 \mathrm{~mm})$ and $30 \%$ gravel $(2$ to $60 \mathrm{~mm})$.

Above the sealing layer, rocky oxide waste rock was loose paddock-dumped in mounds. The particle size distribution of the rocky oxide waste rock used for the mulch layer comprised typically $2 \%$ silt, $26 \%$ sand and $72 \%$ gravel-size and larger. Oxide waste rock with between $25 \%$ and $45 \%$ passing $2 \mathrm{~mm}$ provides reasonable erosion resistance without adversely affecting revegetation potential. The loose dumping ensured a porosity of about 0.25 , which is available for the storage of rainfall infiltration. A $1.5 \mathrm{~m}$ thick mulch layer can therefore store up to $350 \mathrm{~mm}$ of infiltration (about half the average annual rainfall). Any excess water will serve to maintain the sealing layer near-saturated and can pond between the mounds. Provided the sealing layer remains near-saturated, it will limit the diffusion of oxygen into the underlying potentially acid forming waste rock. The mound surface was fertilised and seeded with pasture grasses and native trees. Subsequent field permeability testing of the dozed surface of the loose rocky soil mulch layer, using both the Guelph and CSIRO ring permeameters, indicated a typical saturated hydraulic conductivity of about $2 \times 10^{-}$ ${ }^{6} \mathrm{~m} / \mathrm{s}$.

Figure 2 shows the placement of the rocky soil mulch layer by loose paddock dumping on the compacted clayey layer on the South Dump. The revegetation comprised grasses planted from seed, plus planted acacias and eucalypts, and volunteer acacias. Two years after planting, the grass growth was somewhat diminished due to the consumption of the initial fertiliser application, and acacias were the only other species that survived. More fertiliser was subsequently added to ensure sufficient ongoing consumption of stored water through transpiration, so avoiding the gradual wetting up of the cover over time. However, this additional fertiliser was also exhausted over time and the state of the vegetative cover was further diminished by the prevailing extended dry conditions. While the dry conditions would limit the potential for infiltration through the cover, the lack of a good vegetative cover could also limit the release of infiltration stored in the cover should a wetter than average period occur.

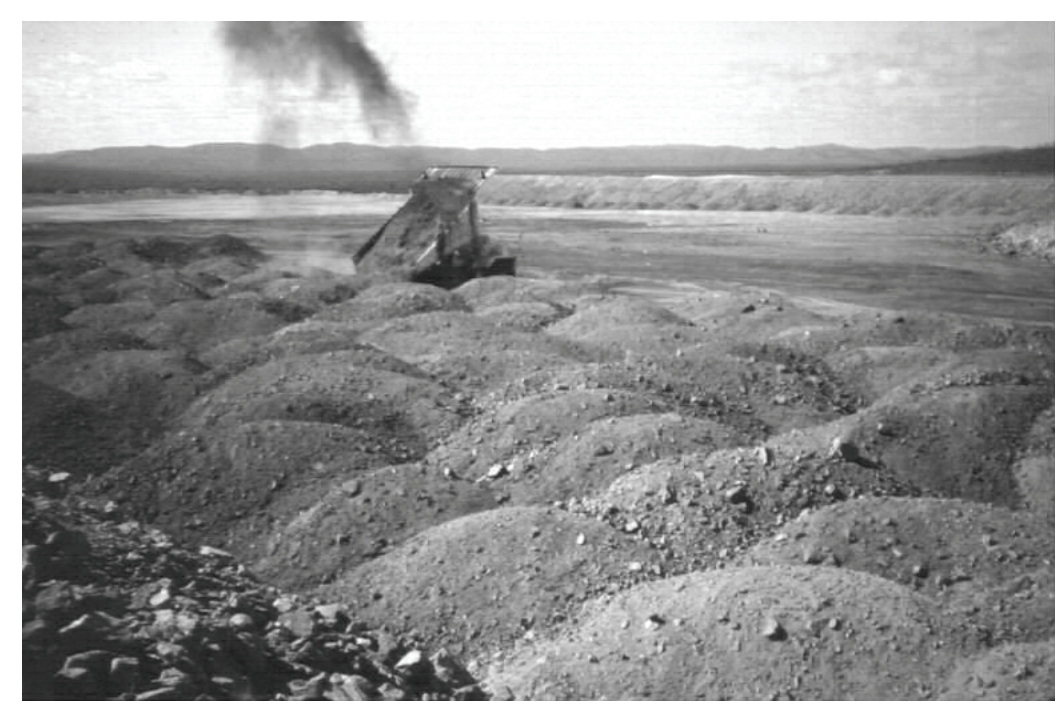

Figure 2 Placement of rocky soil mulch layer on South Dump cover trial

\subsection{Performance Monitoring of South Dump Trial Cover}

Instrumentation of the South Waste Rock Dump trial store/release cover comprised a full weather station established on the top of the dump, large size ( $2.5 \mathrm{~m}$ diameter and height) non-wicking lysimeters used to monitor the effectiveness of the cover in limiting rainfall infiltration, and volumetric water content and matric suction sensors within the cover to provide its seasonal and long-term performance, and any seepage from the toe of the dump was collected (Williams et al., 2006). 
The climatic data were used as input to the computer program SoilCover (Unsaturated Soils Group, 1997) to predict the performance of the cover. Calculations using SoilCover indicated that the average annual rainfall would produce about $1 \%$ net infiltration, while twice the average annual rainfall could produce a net infiltration of $5 \%$ of incident rainfall.

The lysimeter data have shown that infiltration through the trial store and release cover into the mineralised waste rock of the South Dump has averaged less than $0.25 \%$ of incident rainfall, with a maximum recorded infiltration of $1.1 \%$ of incident rainfall since the cover was constructed. A net infiltration of $1 \%$ of the average annual rainfall or $7 \mathrm{~mm} /$ year, which is equivalent to an unsaturated hydraulic conductivity of $2.2 \times 10^{-10} \mathrm{~m} / \mathrm{s}$, is comparable to natural infiltration rates.

The store/release cover has undergone wetting up during each wet season, followed by drying during each succeeding dry season, with the dried-out states at each depth showing little net change over time. After each dry season, the volumetric water content of the upper rocky mulch layer drops to a minimum of about 0.10 (degree of saturation $\mathrm{S}$ of 0.2 and gravimetric moisture content $\mathrm{w}$ of $5 \%$ ), while after the wet season, the average volumetric water content of the cover rises to about 0.35 ( $\mathrm{S} \sim 0.7$ and $\mathrm{w} \sim 20 \%$ ).

Subsequent covers involved smoothing the mounded surface of the paddock-dumped rocky soil mulch a single low bearing pressure dozer pass, which helps to seal off possible preferred seepage paths at the interface between paddock dumps, and enhances revegetation while retaining internal porosity. The revegetation approach has also been modified, with fertilising and native tree-seeding carried out in the first year, followed by refertilising and grass-seeding in the second year. This allows the native trees to become established, rather than be choked out by grasses.

\subsection{Seepage Water Quality and Flow Rates}

Water quality in the main toe seeps from the South and North Waste Rock Dumps has been monitored since late 1986. The monitored water chemistry parameters have included $\mathrm{pH}$, electrical conductivity, sulphate, and a number of metals, including aluminium, arsenic, cadmium, copper and zinc. Dissolved copper and zinc concentrations and $\mathrm{pH}$ levels for the main toe seep from the South Waste Rock Dump are plotted against time on Figure 3, together with some trend lines.

The 1 in 140 year 1990/91 wet season, which followed a low rainfall 1989/90 wet season, generated spikes in $\mathrm{pH}$ (to a low of 3.2) and dissolved metals (dissolved copper to over $50 \mathrm{mg} / \mathrm{l}$ and dissolved zinc to over $100 \mathrm{mg} / \mathrm{l})$. Over the next 10 years, the $\mathrm{pH}$ remained at about 4.5 , and the dissolved copper and dissolved zinc concentrations averaged about $25 \mathrm{mg} / 1$ and $50 \mathrm{mg} / \mathrm{l}$, respectively. Following the completion of the store/release covers over the entire flat top surfaces of the dumps by late 2001, the removal and processing in 2001 of the low grade ore stockpiled within the South Waste Rock Dump footprint, and the diversion to Wises Hill Pit of mine water that previously flowed through the South Dump, the water chemistry of the dump seepage began to improve significantly, apart from the $\mathrm{pH}$, which not unexpectedly has remained constant. The dissolved copper and dissolved zinc concentrations have reduced to $15 \mathrm{mg} / 1$ and $25 \mathrm{mg} / \mathrm{l}$, respectively.

V-notch weirs were installed at the main toe seeps from the South and North Waste Rock Dumps at Kidston in October 2002 and have shown an exponential decline in seepage flow rate over time due to the minimal additional rainfall infiltration since the dumps were covered. Based on the estimated wetting up of the dumps due to rainfall infiltration during the 15-year operation of the mine (Williams and Rohde, 2006), and the measured exponential decline in seepage flow rate since the dumps were covered, the ongoing decline in seepage from the toe of the waste rock dumps shown on Figure 4 was predicted. This prediction was based on the determination of the unsaturated hydraulic parameters of the waste rock comprising the dumps.

Figure 4 shows both the predicted seepage flow rate (left hand vertical scale) and the predicted seepage volume (right hand vertical scale). After about 17 years (end of 2018), the seepage flow rate is predicted to approach that percolating through the cover (about $7 \mathrm{~mm} /$ year) and the seepage volume will be limited to that percolating through the side slopes, which comprise 10 to $15 \%$ of the surface area of the dumps, amounting to ongoing relatively clean seepage at a rate of perhaps $0.15 \mathrm{Mm}^{3} /$ year. 


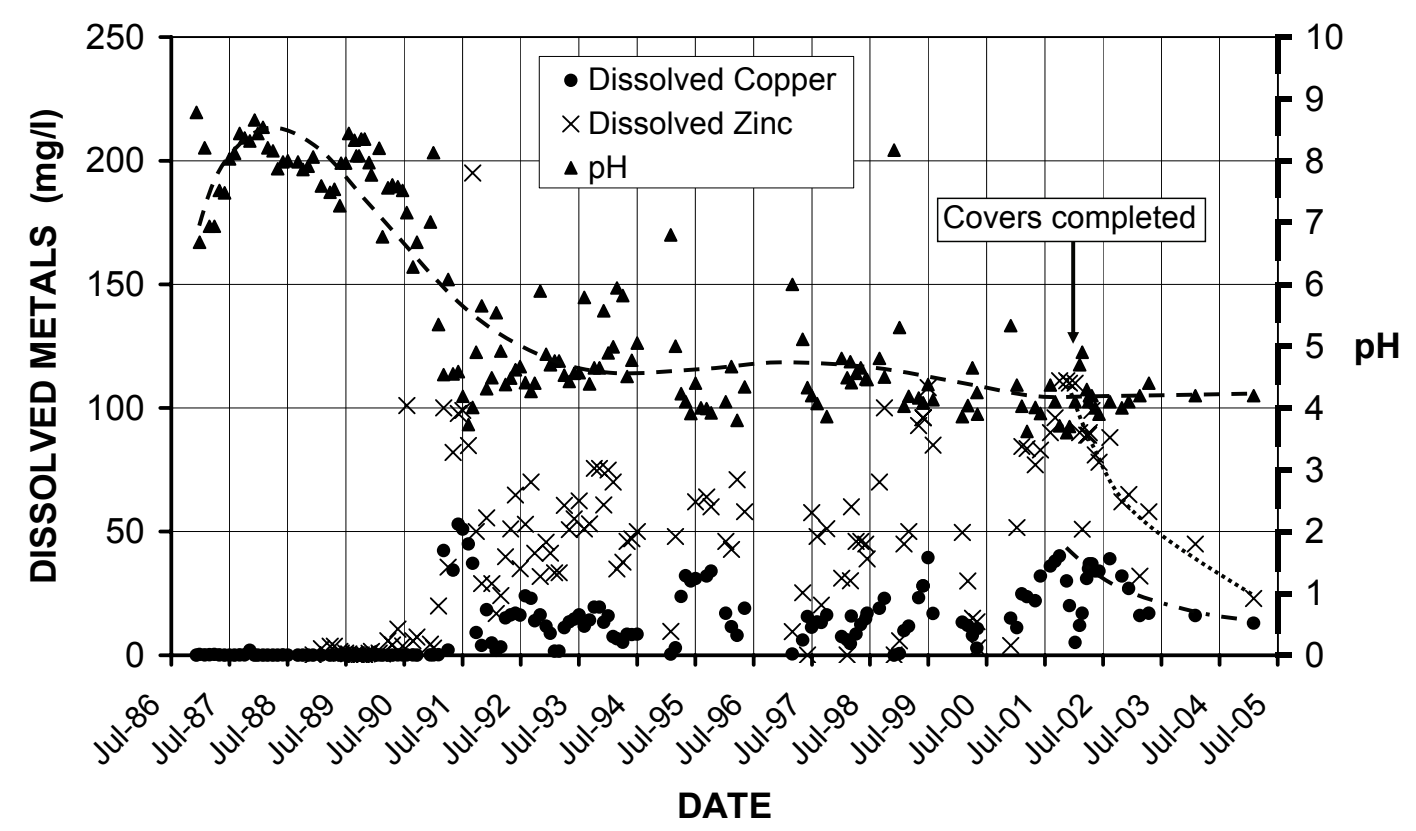

Figure 3 Dissolved copper and zinc concentration and $\mathrm{pH}$ levels for main toe seep from South Dump versus time

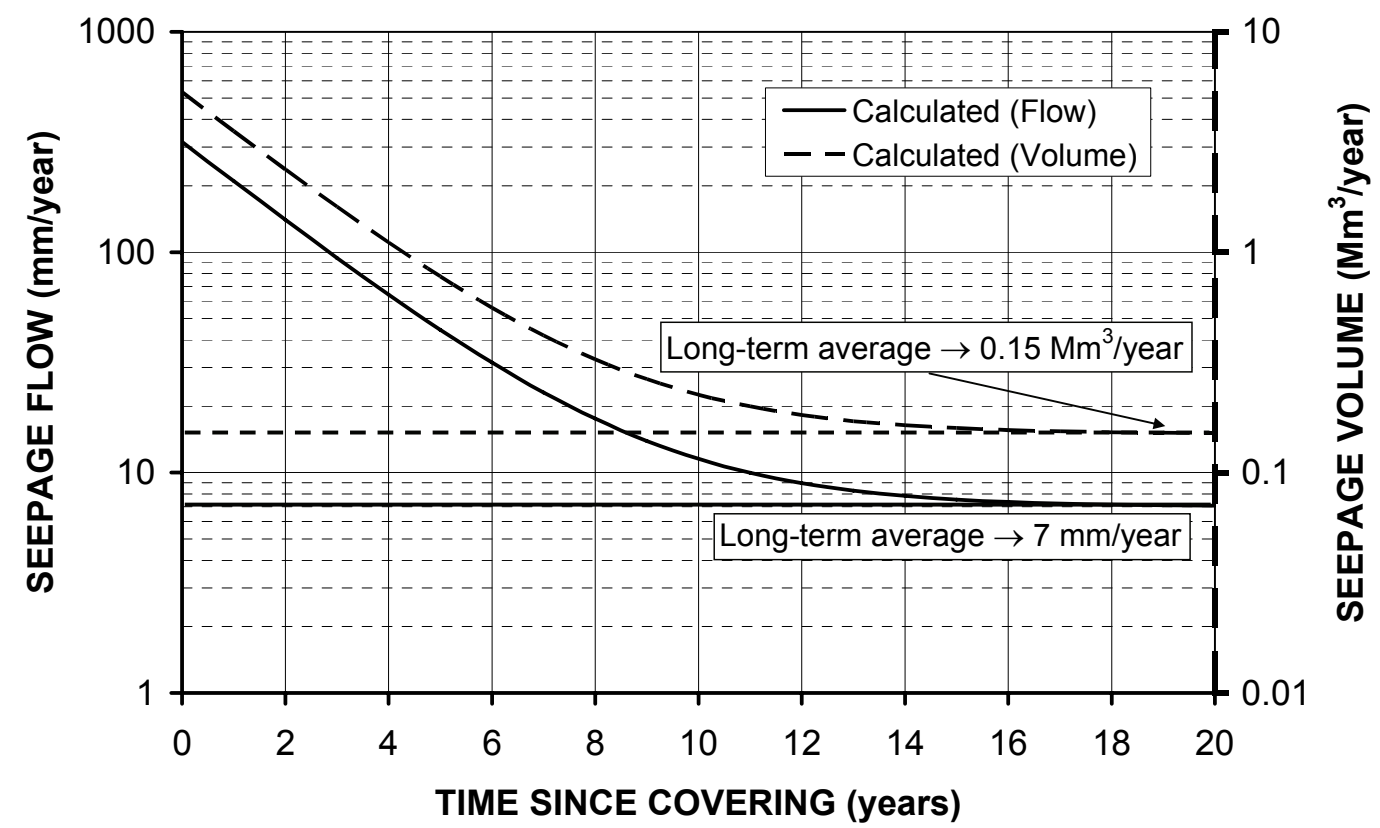

Figure 4 Predicted decline in toe seepage from waste rock dumps

\section{REVEGETATION ASPECTS}

\subsection{Store/Release Cover Vegetation}

The initial South Waste Rock Dump trial store/release cover referred to in Section 2.2 (and as shown in Figures 1 and 2) was aerially seeded in October 1996 with a mix of native and exotic species, and enrichment planted on the top of the mounds with tube stock over the following three years. Fertiliser (CK55 at $200 \mathrm{~kg} / \mathrm{ha}$ ) was applied at the time of sowing, with a further application of $200 \mathrm{~kg} / \mathrm{ha}$ in June/July 
1999. The simultaneous seeding of tree/shrub and pasture species on the older-established South Dump (SBD) led, due to intense grass competition, to a vegetation community with a sparse upper storey layer and a ground cover dominated by the introduced grasses, Buffel and Rhodes grass.

The North and East Dump tops were aerially seeded with shrub and tree species in December 2001, and subsequently with pasture species in January 2003. Fertiliser (CK55 at $100 \mathrm{~kg} / \mathrm{ha}$ ) was applied at the initial seeding, and a further $200 \mathrm{~kg} / \mathrm{ha}$ was applied with the pasture species. The change in strategy for the broad scale seeding of these dump tops, led to a more rapid development of a tree and shrub layer, and also resulted in an increase in the range of native grass species successfully colonising the site.

It is well recognised that vegetation is a key contributor to the proper functioning of the store/release cover system, and the progression and structural composition of the vegetation communities developing on the constructed dump covers have been monitored over several years. In 2005, the vegetation on the South Dump was 8.5 years old and that on the North and East Dumps was 3.5 years old. As described elsewhere in this proceedings (Mulligan et al., 2006), a set of interim targets for various plant and soil parameters was developed for Kidston, based on averages from a number of unmined communities in the surrounding local and regional landscapes (Bowen, 2001). The generation of such targets is useful as a means of assessing "success" and community progression and stability, but recognising that it is an iterative process, and a revisit of these 'targets' may be necessary as more monitoring information is accumulated over time.

A summary of some of the vegetation characteristics for the waste rock dump sites and comparisons with two unmined "analogue" sites (the Airstrip and Copperfield sites) are presented on Figures 5 and 6. Figures 5 and 6 show the often quite rapid development of structural similarities between the mined and unmined sites. While the species richness and diversity levels of the analogue sites is not yet being detected through the monitoring programs on the rehabilitation areas, the surface roughness and the increasing amount of leaf litter that is now accumulating in the landscape of even the youngest sites, does provide the opportunity for these sites to progress towards meeting agreed end-point criteria.

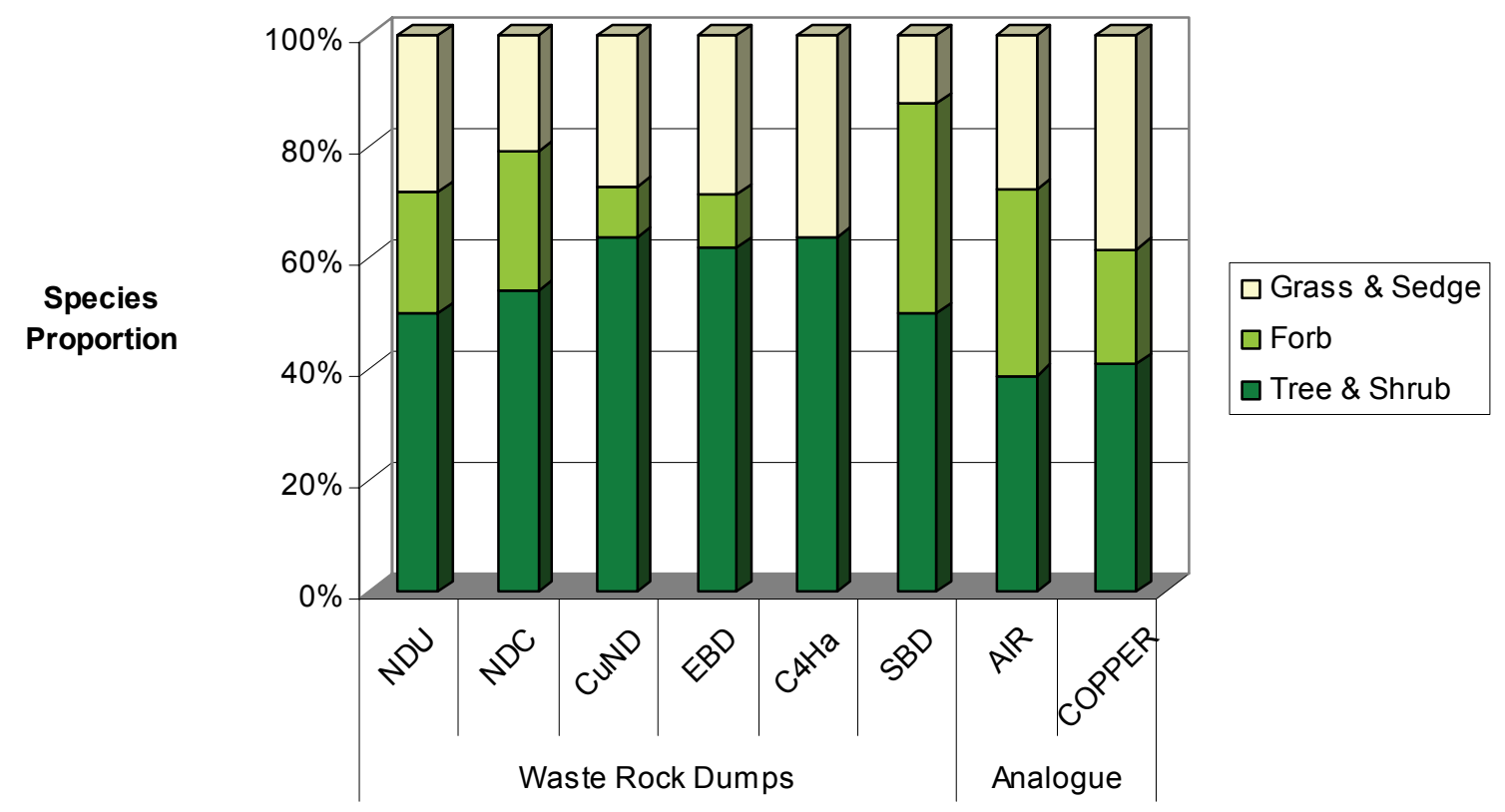

Figure 5 Proportions of species in each life form for waste rock and analogue sites

The vegetation characteristics for the North Dump in 2005, established 3.5 years, are summarised in Table 1, and the state of the shrub and tree development after 2 years are shown on Figure 7. 


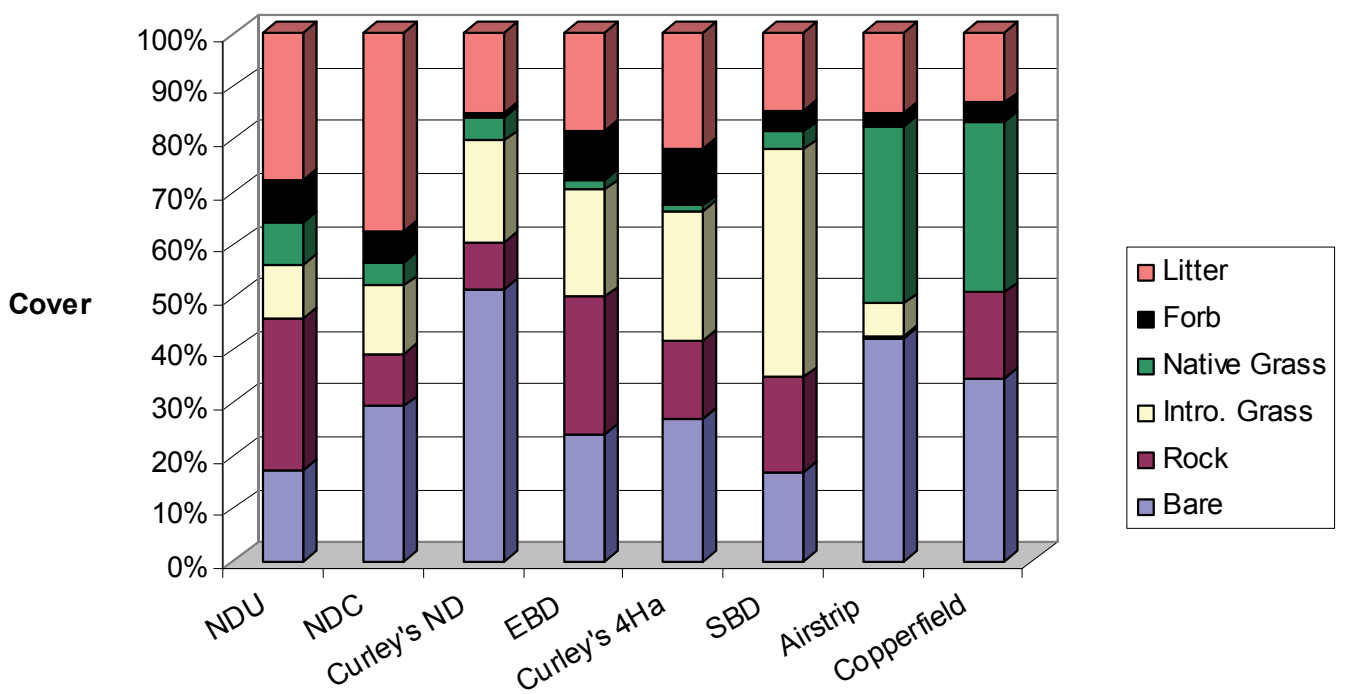

Waste Rock Dump and Native Sites

Figure 6 Cover proportions for waste rock dump sites compared to analogue sites

Table 1 Vegetation characteristics for North Dump in 2005, established 3.5 years

\begin{tabular}{|l|c|c|c|c|c|}
\hline Species richness and diversity & No. or index & Target & Target met? & Airstrip & Copperfield \\
\hline Native trees and shrubs & 16 & 10 & yes & 14 & 16 \\
\hline Woody genera & 4 & 7 & no & 11 & 12 \\
\hline Eucalyptus/Corymbia & 8 & 3 & yes & 4 & 2 \\
\hline Simpson's diversity index & 0.37 & 0.15 & no & 0.14 & 0.18 \\
\hline Woody species density & No. per ha & Target & Target met? & Airstrip & Copperfield \\
\hline Eucalyptus/Corymbia & 983 & $>15 \%$ of total & yes & 158 & 237 \\
\hline Acacia & 933 & $<30 \%$ of total & yes & 0 & 75 \\
\hline Other & 2650 & $>30 \%$ of total & yes & 308 & 475 \\
\hline Total & 4566 & & & 466 & 787 \\
\hline Ground cover & $\mathbf{\%}$ & Target & Target met? & Airstrip & Copperfield \\
\hline Vegetation & 26 & $>30 \%$ & no & $42 \%$ & $36 \%$ \\
\hline Litter & 28 & $>15 \%$ & yes & $15 \%$ & $13 \%$ \\
\hline Bare & 46 & $<30 \%$ & no & $43 \%$ & $51 \%$ \\
\hline
\end{tabular}

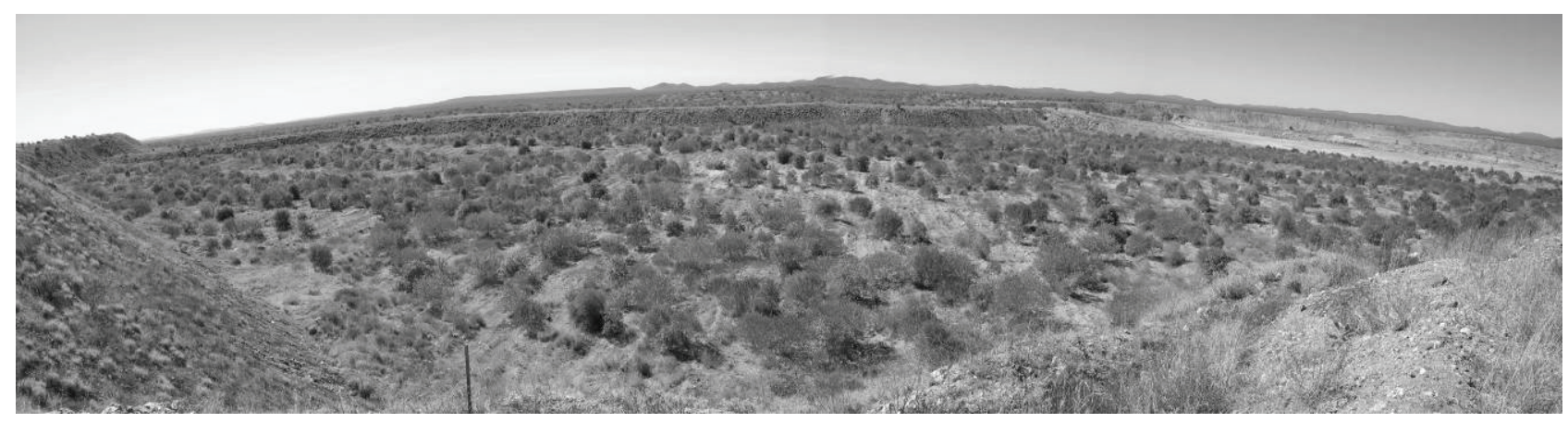

Figure 7 A view across top of North Dump, 2 years after shrub and tree seeding 


\subsection{Vegetation of Angle-of-Repose Outer Batters}

Revegetation of the angle-of-repose outer dump batters was required not only to assist with the stabilisation of the batters, but also to improve their appearance. Because of the steepness of the batter face (angle of repose of $37^{\circ}$ ), runoff could act to continually to destabilise the oxide-covered surface and thus make it difficult for vegetation to establish. For this reason, the seeding rates of grasses were high and a higher proportion of nitrogen-fixing species than would normally be the case was used. The high proportion of nitrogen-fixing species was designed to provide a longer-term contribution of nitrogen into the soil to supply the higher demands of the faster-growing introduced pasture grasses.

The seed was applied aerially by helicopter in two stages with the first application taking place in January 2001. Backup seeding was done in December 2001, particularly on those areas where the seed strike from the first application was less successful. Fertiliser application was also done in two stages, the first at an application rate of $500 \mathrm{~kg} / \mathrm{ha}$ of DAP (Diammonium Phosphate), and a second at $300 \mathrm{~kg} / \mathrm{ha}$ of DAP.

The outer batter slopes have been monitored both through measurements of erosion pin sets at the foot of various sections of the dump, and a photographic record maintained on an annual basis since 2001. The nature of the oxide deposition process from the crest of the dump meant that the loose unconsolidated material over the barren wast rock would run down the slope with rainfall events, but the proportion that is held up within and between the crevices of the blocky rock beneath has created a very effective sink for fines and other resources that provide the basis for encouraging a persistent vegetative cover. Figure 8 illustrates the effectiveness of this strategy, and over time, evidence suggests that vegetative colonisation of the batter slopes will proliferate.

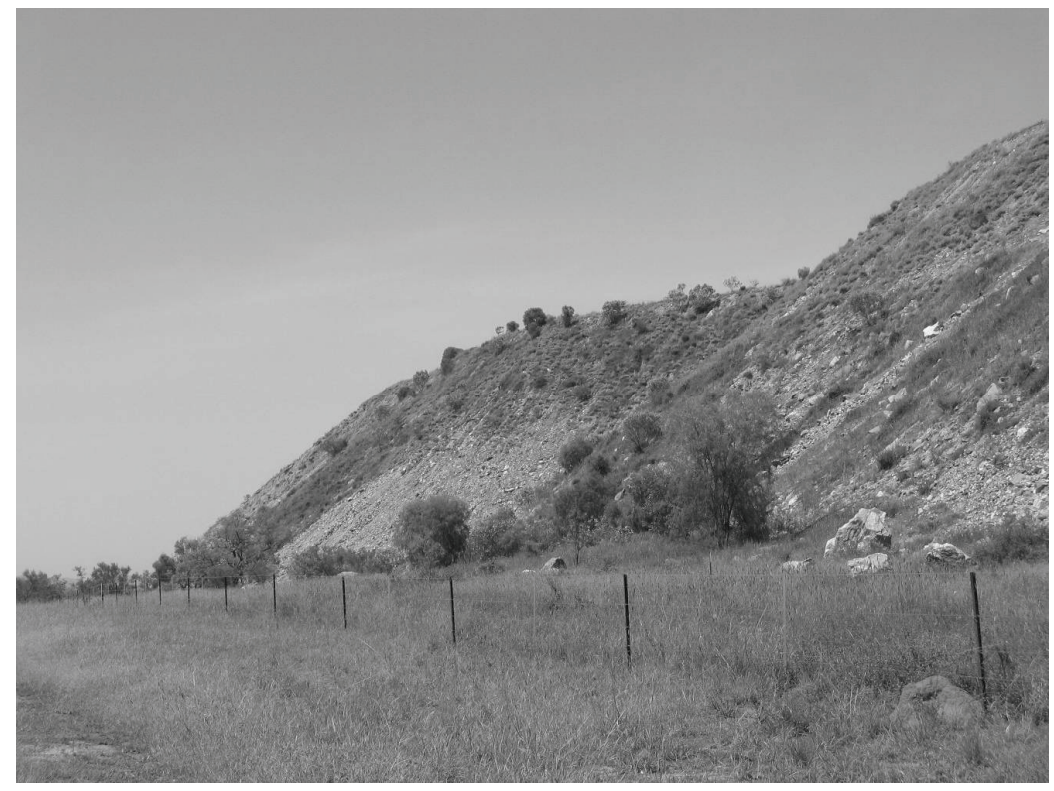

Figure 8 Revegetation of outer batter of East Dump within 3 years of seeding

\section{CONCLUSION}

The key elements of the Kidston waste rock dump design are a base pad of fresh barren waste rock, with a wide encapsulation (up to $60 \mathrm{~m}$ horizontally) of fresh barren waste rock, leaving the side slope at the angle of repose of the material, and end-dumping a partial cover of oxide waste rock from the crest to facilitate revegetation.

The key elements of the store/release cover system developed for Kidston are a $0.5 \mathrm{~m}$ thick compacted sealing layer, overlain by a minimum $1.5 \mathrm{~m}$ thick rocky soil mulch store/release layer with a dozed mounded surface that is revegetated. Reducing the amplitude of the mounds by means of a single dozer pass helps to seal off possible preferred seepage paths at the interface between paddock dumps, and enhances revegetation while retaining internal porosity. The choice of appropriate vegetation to transpire excess stored water from 
the rocky mulch layer is vital to maintaining the function of the store/release cover system. Trees are best planted in the first year of revegetation, with grasses seeded in the second year. A eucalypt tree cover represents the only sustainable means of achieving sufficient transpiration in the long-term.

Over the 9 years of monitoring, the maximum recorded infiltration through the trial store/release cover has been $1.1 \%$ of incident rainfall, although most of these years have experienced below average annual rainfall. The instrumented store/release covers have undergone annual cycles of wetting up during each wet season, followed by drying during each succeeding dry season, with the dried-out states at each depth within the cover showing little net change over time. The water quality of the seepage emanating from the waste rock dumps at Kidston has improved significantly and the seepage flow rate has reduced significantly since the store/release covers were completed. The seepage water quality is expected to improve further and the seepage flow rate is predicted to approach the slow rate of percolation through the store/release cover within about 17 years (by about 2018).

\section{ACKNOWLEDGEMENTS}

The authors gratefully acknowledge the management of Placer Dome Asia Pacific for providing access to the data on which this paper is based and for allowing publication of these data.

\section{REFERENCES}

Bowen, D. (2001) Rehabilitation monitoring manual. Methods for the assessment of rehabilitation and criteria for determining rehabilitation success at Kidston gold mine. Report prepared for Kidston Gold Mines Ltd, July 2001. Centre for Mined Land Rehabilitation, The University of Queensland.

Kidston Gold Mines Limited (2000) Closure Plan and Environmental Report.

Mulligan, D.R., Gravina, M.J., Gillespie, M.J., Lockhart, C. and Currey, N.A. (2006) An assessment of the direct revegetation strategy on the tailings storage facility at Kidston gold mine. To appear in Proceedings of First International Seminar on Mine Closure, 13-15 September 2006, Perth, Western Australia.

Unsaturated Soils Group (1997) SoilCover, User's Manual, Version 4.0. Unsaturated Soils Group, University of Saskatchewan, Saskatoon, Canada.

Williams, D.J. and Rohde, T.K. (2006) Rainfall infiltration-induced seepage from waste rock piles. To appear in Proceedings of Water in Mining 2006, Brisbane, Australia, 14-16 November 2006.

Williams, D.J., Stolberg, D.J. and Currey, N.A. (2006) Long-term performance of Kidston's "store/release" cover system over potentially acid forming waste rock dumps. Proceedings of Seventh International Conference on Acid Rock Drainage, St Louis, Missouri, USA, 26-30 March 2006, pp. 2385-2396.

Williams, D.J., Wilson, G.W. and Currey, N.A. (1997) A cover system for a potentially acid forming waste rock dump in a dry climate. Proceedings of Fourth International Conference on Tailings and Mine Waste '97, Fort Collins, CO, 13-17 January, 1997, pp. 231-235. A.A. Balkema, Rotterdam. 